\title{
中国油气区第三系与欧美标准层序的对比
}

\author{
中国石油天然气总公司第三系研究课题协调组
}

\section{关筧调 中国油气区、第三系}

中国油气区第三系以陆相为主,仅在我国新疆、台湾和东南海域等地有海相沉积. 在广泛 分布的第三系内,已找到了丰富的油气藏. 因此, 为深入研究和总结含油气规律, 指导今后的 油气勘探,编制国内外第三纪地层对比表是十分必要的.

自 1987年起,中国石油天然气总公司组织了第三系研究专题组, 对全国油气区的地层、生 物群、“三古”和油气资源预测等进行了较为深人的研究。在地层对比方面,除继续完善各含油 气盆地间的对比外,通过海、陆各门类微体化石、脊椎动物化石、磁性地层学和火山岩年代地层 学的研究,首次提出了我国油气区与欧美第三纪标准层序的对比方案(见表 1$)^{[1-6)}$.

致谢: 中国石油天然气总公司勘探开发科学研究院，大庆、胜利、江河、华东、中原、大港、玉门、青海、长 庆、新琵、吉林、江苏、河南、江汉、安徽、滇領桂和广西等油田的地质科学研究院, 新疆塔里木石油勘探指挥 部, 浙江石油地质研究所, 大庆石油学院, 以及中国海洋石油总公司的渤海、东海、南海东部和南海西部石油 公司, 共 25 个单位, 参加了本课题的工作. 中国科学院古余椎动物与古人类研究所李传乘、童永生、黄学诗 提供了古瓷椎动物组合及其地层层序的资料, 在此一并致谢.

\section{今齐献}

[1] 李云通等,中国第三系,中国地层 13, 地质出版社, 1984.

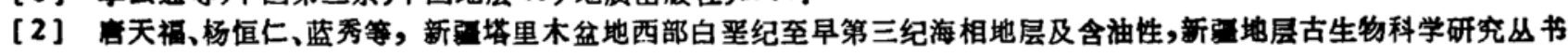
之一,科学出版社, 1989 .

[3] 地质矿产部海洋地质综合研究大队、中国地质科学院地质研究所, 东海陆架新生代古生物群,改体古植物分册, 地质 出版社, 1989 .

[4] Martini, E., Standard Tertiary and Quatarnary calcareous nannoplankton zonation, Proceedings II, Plankzonic Conference Roma, 1970, 2. 739-785.

[5] Woodburne. M. O. (ed.), Cenozoic Mammals of North America Geochronology and Biostrat igraphy. University of California Press, Berkery, 1987.

[6] Schmidt-Kittler. N. (ed.). International Symposium on Mammalian Biostratig raphy and Paleoecolog of the European Paleogene, Münchner Geowiss. Abh., (A) 10, 1987.

- 本文 1991 年3 月25 日收到. 
表 1 中国油气区第三纪部分海、陆相剖面与欧、美标准层序对比表

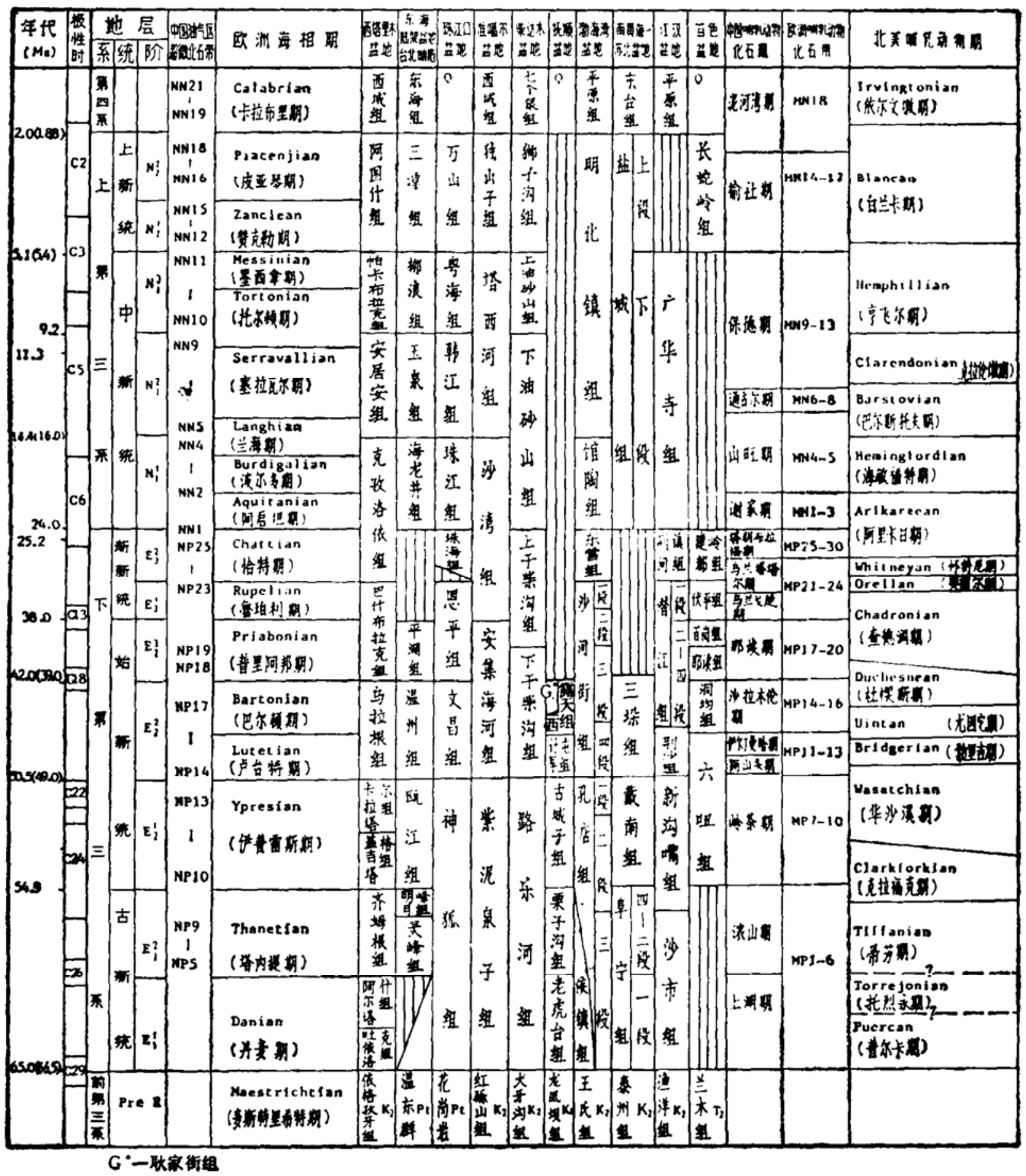

